Revised version

Organic Geochemistry 21, 517-523, 1994.

doi:10.1016/0146-6380(94)90102-3

Correspondence: Dr. Eric Lichtfouse, INRA-CMSE-PME, 17, rue Sully, 21000 Dijon, France

Eric.Lichtfouse@dijon.inra.fr

\title{
Accelerated transformation of organic matter below the silica transition zone in immature sediments from the Japan Sea*
}

\author{
Eric Lichtfouse $^{1 \#}$ and Jürgen Rullkötter ${ }^{2}$ \\ ${ }^{1}$ Laboratoire de biogéochimie isotopique, associé à l'Institut National de la Recherche Agronomique, \\ Université Pierre et Marie Curie, 4, place Jussieu, Case 120, F-75252 Paris Cedex 05, France. \\ ${ }^{2}$ Institut für Chemie und Biologie des Meeres, Carl von Ossietzky Universität Oldenburg, Postfach 2503, D- \\ 26111 Oldenburg, Germany.

\begin{abstract}
Notable compositional changes of organic matter are observed below the silica transition zone in thermally immature sediments. The increase of bitumen ratio, and hopane and sterane isomerisation parameters indicate an acceleration of the kinetics of the chemical reactions which transform the organic matter. This phenomenon is probably due to the numerous mineral and textural changes induced by the transformation of amorphous biogenic silica into crystalline authigenic silica.
\end{abstract}

Key words - Japan Sea, sediment, silica, hopane, sterane, molecular parameter.

\section{INTRODUCTION}

Diatoms, radiolarians and silicoflagellates precipitate amorphous silica to form siliceous tests, which accumulate on the sea floor to form siliceous oozes. With increasing burial, a less soluble Cristobalite-Tridymite phase, opal-CT, forms and then recristallizes to still less soluble quartz. This transformation depends on temperature, time, rock composition, interstitial water composition and particle surface area (Williams et al., 1985).

In the immature sediments from the Japan Sea, at Ocean Drilling Project Sites 798 and 799 , the diagenetic mineral sequence opal-A/opal-CT/quartz forms a major lithological and geochemical boundary, and is thus accompanied by abrupt changes in texture, porosity, density, soluble silica, water content, gas concentrations and total organic carbon within a relatively short depth interval (Ingle et al., 1990). We report here several notable changes in gross composition of organic matter and of biological marker ratios below the zone of silica diagenesis.

\section{SAMPLES AND METHODS}

Mineral and bulk organic matter analysis of the rocks from two cores of the Ocean Drilling Program, recovered on the Oki Ridge (Site 798, 41-518 $\mathrm{m}$ ) and in the Kita-Yamato Trough (Site 799, 47-1082 m), are decribed elsewhere (Ingle et al., 1990, Lichtfouse et al., 1992 ). In those cores, biosiliceous sedimentary rocks form a major component with an unusually clear record of silica diagenesis with depth. At Oki Ridge, the opal-A/opal-CT boundary is found at 455 $\mathrm{m}$ depth and the opal-CT/quartz transition was not reached. In the Kita-Yamato Trough, the opalA/opal-CT and opal-CT/quartz boundaries are at $410 \mathrm{~m}$ and $585 \mathrm{~m}$ depth, respectively. Dominant lithologies include diatomaceous ooze, diatomaceous clay and silty clay above the silica transition zone, and siliceous claystone and porcellanite below this zone.

\footnotetext{
* presented at the 3rd Latin American Congress on Organic Geochemistry, Manaus, Brazil, 1992.

\# author to whom correspondence should be addressed.
} 
Total organic carbon (TOC) was determined by combustion in a LECO IR-112 carbon analyser. Extraction and fractionation of the soluble organic matter was completed as follows: ground rock is dried and extracted with dichloromethane-methanol $(99 / 1 \mathrm{v} / \mathrm{v})$. The extract is filtered and concentrated under reduced pressure to yield bitumen which is separated into saturated hydrocarbon, aromatic hydrocarbon and polar fractions by medium pressure liquid chromatography (Radke et al., 1980).

Saturated hydrocarbon fractions were analysed by gas chromatography (GC) and gas chromatography-mass spectrometry (GC-MS). GC conditions: Varian 3700 analyser, split injection (1/3), injector temperature $300^{\circ} \mathrm{C}$, fused silica capillary column $(50 \mathrm{~m}, 0.32 \mathrm{~mm}$ i.d. $)$, $100 \%$ methylpolysiloxane phase $(0.52 \mu \mathrm{m}$ film thickness $)$, temperature program: $120^{\circ} \mathrm{C}(2 \mathrm{~min})$, $120-320^{\circ} \mathrm{C}(3 \% \mathrm{~min}), 320^{\circ} \mathrm{C}(60 \mathrm{~min})$, helium flow: $3 \mathrm{ml} / \mathrm{min}$, flame ionization detector. $\mathrm{MS}$ conditions: electron impact, $70 \mathrm{eV}, \mathrm{VG} 7070 \mathrm{E}$ mass analyser (EB Type), mass range: 43-800 a.m.u. Saturated hydrocarbons were identified by comparison of their mass spectra and chromatographic behavior with literature data: hopanes using Ensminger et al. (1974) and van Dorsselaer et al. (1974, 1977b), steranes using Seifert and Moldowan (1979) and Moldowan et al. (1980). $C_{31}$ hopane stereoisomers were better selected using the $\mathrm{m} / \mathrm{z}=426$ fragmentogram rather than the classical $\mathrm{m} / \mathrm{z}=191$ fragmentogram. Examples of hopane and sterane molecular structures are drawn in Figure 1.

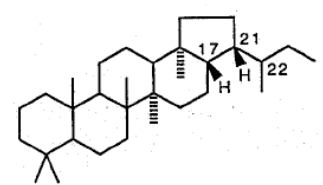

$C_{31} \beta \beta R$-Hopane

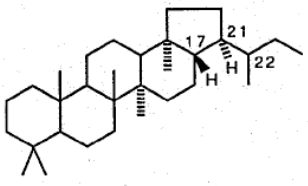

$\mathrm{C}_{31} \beta \alpha \mathrm{R}$-Hopane

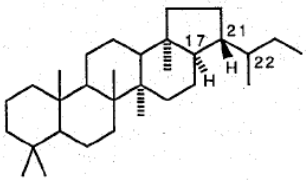

$\mathrm{C}_{31} \alpha \beta \mathrm{R}$-Hopane

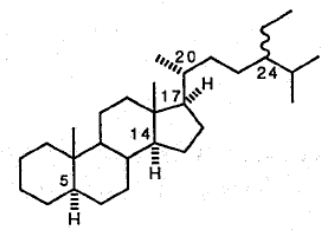

$\mathrm{C}_{29} \alpha \alpha \alpha \mathrm{R}$-Sterane<smiles>CC[C@]12CCCCC1(C)C1CCC3[C@@H]([C@H](C)CCC(SC)C(C)C)CC[C@]3(C)C1CC2</smiles>

$\mathrm{C}_{29} \beta \alpha \alpha \mathrm{R}-$ Sterane

Figure 1. Molecular structure of hopanes and steranes identified in the Japan Sea sedimentary rocks. The numbers correspond to the carbon positions which undergo epimerization with increasing burial: $\beta \beta R$ refers to $17 \beta, 21 \beta 22 \mathrm{R}$, $\alpha \alpha \alpha \mathrm{R}$ refers to $5 \alpha, 14 \alpha, 17 \alpha 20 \mathrm{R}$. $24 \mathrm{R}$ and $24 \mathrm{~S} \mathrm{C}_{29}$ sterane epimers are not separated by routine gas chromatography (Maxwell et al., 1980). 
Table 1. Total Organic Carbon (TOC), bitumen ratio, hopane and sterane parameters versus depth in Oki Ridge and Kita-Yamato Trough cores from the Japan Sea. The bitumen ratio is the organic extract normalized to TOC (Tissot and Welte, 1984). Hopane and sterane parameters are calculated from peak heights in the $\mathrm{m} / \mathrm{z}=426$ and 217 reconstructed ion chromatograms: $\alpha \beta / \beta \beta(\%)=100 \mathrm{x}$ $\alpha \beta R /(\alpha \beta R+\beta \beta R), \beta \alpha / \beta \beta(\%)=100 \times \beta \alpha R /(\beta \alpha R+\beta \beta R), \beta \alpha \alpha / \alpha \alpha \alpha=100 \times \beta \alpha \alpha R /(\beta \alpha \alpha R+\alpha \alpha \alpha R) . C_{27}$ $(\%), C_{28}(\%), C_{29}(\%)$ are calculated with heights of corresponding $\alpha \alpha \alpha R$ steranes. n.d.: not determined because fraction amounts are too low. *: not used in the figures because very low values of TOC may lead to inaccurate normalizations.

\section{DEPTH TOC BITUMEN HOPANES STERANES}

$\begin{array}{lllllllll}(\mathrm{m}) & (\%) & (\mathrm{mg} / \mathrm{gTOC}) & \alpha \beta / \beta \beta & \beta \alpha / \beta \beta & \beta \alpha \alpha / \alpha \alpha \alpha & \mathrm{C}_{27} & \mathrm{C}_{28} & \mathrm{C}_{29}\end{array}$
(\%)
(\%)
(\%)
(\%) (\%)
(\%)

Oki Ridge (Site 798):

$\begin{array}{rrrrrrrrr}41.50 & 3.82 & 11.3 & 24 & 7 & 25 & 40 & 29 & 31 \\ 66.69 & 3.78 & 17.4 & 19 & 7 & 28 & 37 & 27 & 36 \\ 96.54 & 4.50 & 32.9 & 9 & 1 & 21 & 43 & 32 & 25 \\ 120.63 & 2.74 & 23.9 & 16 & 6 & 32 & 44 & 28 & 28 \\ 131.38 & 2.82 & 26.6 & 16 & 3 & 22 & 32 & 17 & 51 \\ 201.26 & 3.22 & 28.2 & \text { n.d. } & \text { n.d. } & \text { n.d. } & \text { n.d. } & \text { n.d. } & \text { n.d. } \\ 249.42 & 1.82 & 29.5 & 22 & 8 & \text { n.d. } & \text { n.d. } & \text { n.d. } & \text { n.d. } \\ 332.65 & 1.77 & 31.2 & \text { n.d. } & \text { n.d. } & \text { n.d. } & \text { n.d. } & \text { n.d. } & \text { n.d. } \\ 373.52 & 1.90 & 26.5 & 38 & 13 & 29 & 49 & 16 & 35 \\ 446.22 & 1.16 & 10.6 & \text { n.d. } & \text { n.d. } & \text { n.d. } & \text { n.d. } & \text { n.d. } & \text { n.d. } \\ 504.20 & 4.41 & 12.1 & 24 & 9 & \text { n.d. } & \text { n.d. } & \text { n.d. } & \text { n.d. } \\ 518.07 & 4.32 & 19.1 & \text { n.d. } & \text { n.d. } & \text { n.d. } & 44 & 27 & 29\end{array}$

\begin{tabular}{rrrrrrrrr}
\multicolumn{1}{l}{ Kita-Yamato Trough (Site 799): } & & & & & & \\
47.66 & 0.96 & $76.7^{*}$ & n.d. & n.d. & n.d. & n.d. & n.d. & n.d. \\
109.98 & 1.03 & 15.4 & 30 & 5 & n.d. & n.d. & n.d. & n.d. \\
110.02 & 5.85 & 17.8 & 9 & 1 & n.d. & n.d. & n.d. & n.d. \\
110.08 & 1.46 & 15.0 & n.d. & n.d. & n.d. & n.d. & n.d. & n.d. \\
144.94 & 3.03 & 15.2 & 21 & 9 & 27 & n.d. & n.d. & n.d. \\
159.15 & 2.55 & 14.7 & n.d. & n.d. & n.d. & n.d. & n.d. & n.d. \\
207.75 & 1.29 & 21.0 & n.d. & n.d. & n.d. & n.d. & n.d. & n.d. \\
265.05 & 1.23 & 23.5 & n.d. & n.d. & n.d. & n.d. & n.d. & n.d. \\
347.35 & 0.78 & $29.5^{\star}$ & n.d. & n.d. & n.d. & 36 & 31 & 33 \\
388.73 & 1.96 & 18.8 & 26 & 11 & n.d. & 40 & 22 & 38 \\
459.62 & 1.16 & 16.9 & 16 & 5 & n.d. & n.d. & n.d. & n.d. \\
500.72 & 3.09 & 15.9 & n.d. & n.d. & 26 & 35 & 35 & 30 \\
533.36 & 2.32 & 21.6 & 41 & 13 & n.d. & n.d. & n.d. & n.d. \\
570.51 & 4.97 & 24.2 & 34 & 7 & 40 & 30 & 40 & 30 \\
600.83 & 2.49 & 22.2 & 44 & 20 & n.d. & 44 & 27 & 29 \\
620.12 & 2.02 & 33.6 & 41 & 20 & 39 & 35 & 33 & 32 \\
657.07 & 1.39 & 40.0 & n.d. & n.d. & 41 & 33 & 34 & 33 \\
721.13 & 1.95 & 33.8 & 72 & 43 & 40 & 35 & 32 & 33 \\
885.26 & 3.11 & 55.7 & 81 & 70 & 39 & 33 & 34 & 33 \\
953.71 & 3.07 & 58.5 & 83 & 59 & 42 & 37 & 35 & 28 \\
1033.98 & 0.62 & 61.1 & 88 & 76 & 45 & 34 & 33 & 33 \\
1081.89 & 3.35 & 67.8 & 96 & 83 & 20 & 35 & 33 & 32
\end{tabular}




\section{RESULTS AND DISCUSSION}

\section{Bitumen ratio}

With increasing burial depth, the bitumen ratio decreases slightly from 25 to $15 \mathrm{mg} / \mathrm{g}$ TOC within the silica transition zone, then increases rapidly to about $60 \mathrm{mg} / \mathrm{g} \mathrm{TOC}$ in the deepest rocks (Figure 2, Table 1). Similarly drastic variations of saturated hydrocarbon and aromatic hydrocarbon contents occur below this zone (Lichtfouse, unpublished results). Such variations have been previously observed during the first stage of catagenesis of organic matter, thus indicating the beginning of petroleum generation (Tissot and Welte, 1984). However, in the deepest rocks of the Japan Sea, the organic matter has not reached the catagenetic stage as shown by low hopane and sterane epimerization ratios: $S /(S+R)=30 \%$ and $14 \%$ respectively, in the deepest rock cored at $1082 \mathrm{~m}$ depth at Kita-Yamato Trough. Moreover, Tmax values, recorded by Rock-Eval pyrolysis, are typical of immature organic matter and do not increase significantly through the cores (Lichtfouse et al., 1992).

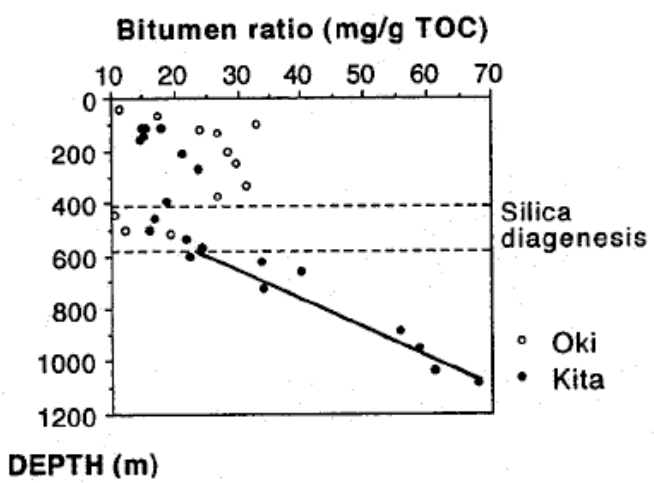

Figure 2. Bitumen ratio versus depth at Oki Ridge ("Oki") and Kita-Yamato Trough ("Kita"), showing the rapid increase of this ratio below the silica transition zone.

\section{Hopane parameters}

$\mathrm{C}_{31}$ hopanes, derived from eubacterial precursors (Ourisson et al., 1979), show a typical evolution from the "natural" $\beta \beta R$ configuration to the more stable $\beta \alpha R$ and $\alpha \beta R$ configurations with increasing burial depth (Figure 3). Such changes usually reflect the increase of thermal maturity in sediments (Ensminger et al., 1977; van Dorsselaer et al., 1977a; Mackenzie et al., 1980). The relative concentration of 22S- versus 22R-homohopanes also increases and reaches a value of $30 \%$ in the deepest sedimentary rock at $1082 \mathrm{~m}$ depth, indicating that the organic matter is still at the diagenetic stage ("immature").

In addition to the regular increase expected with increasing burial, or thermal maturity, the hopane parameters show a drastic increase below the silica transition zone (Figure 4). These transformations at the molecular level indicate an acceleration of the chemical reactions which control the distributions of hopane isomers. These variations go along with the abrupt mineral changes observed at the silica transition zone within a short depth interval (Ingle et al., 1990): at Kita-Yamato Trough, for example, the ODP scientists recorded (1) a decrease in dissolved silica in interstitial waters from $1450 \mu \mathrm{M}$ at $436 \mathrm{~m}$ depth to $860 \mu \mathrm{M}$ at $465 \mathrm{~m}$ depth; (2) an increase in bulk density from 1.4 to $1.7 \mathrm{~g} / \mathrm{cm}^{3}$ at about $459 \mathrm{~m}$ depth and (3) a decrease of porosity from 75 $\%$ to $58 \%$ at about $460 \mathrm{~m}$ depth. Notable increases of methane and organic carbon contents have also been reported. Hence, the transformation of the organic substances at this stage could be catalysed by siliceous minerals, as suggested by heating experiments on clays (Rubinstein et al., 1975, Sieskind et al., 1979). 


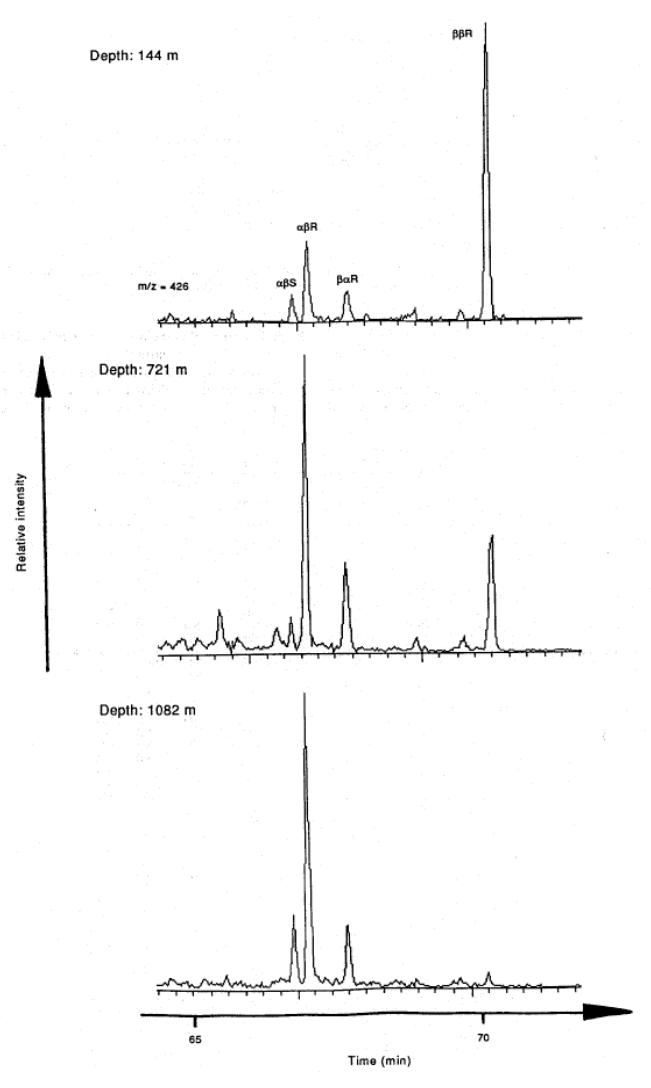

Figure 3. Reconstructed ion currents at $\mathrm{m} / \mathrm{z}=$ 426 showing the distributions of $\mathrm{C}_{31}$ hopane stereoisomers in the organic extracts of the Japan Sea sedimentary rocks. Note the relative increase of $\alpha \beta R$ and $\beta \alpha R$ versus $\beta \beta R$ hopane with increasing depth. The deepest rock has not reached the catagenetic stage of organic matter as indicated by the low relative intensity of the $22 \mathrm{~S}$ epimer: $\alpha \beta S \times 100 /(\alpha \beta S+\alpha \beta R)=30 \%$.

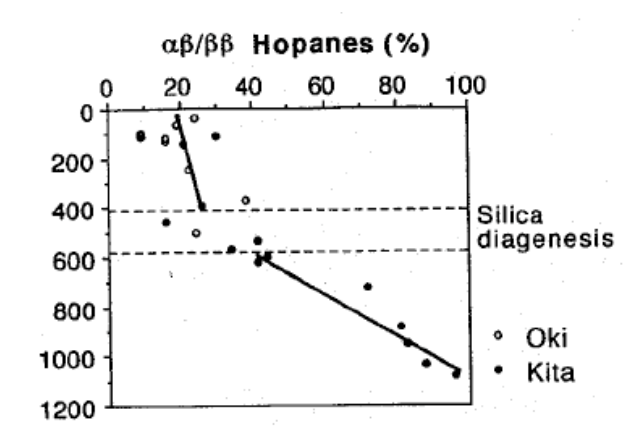

DEPTH (m)

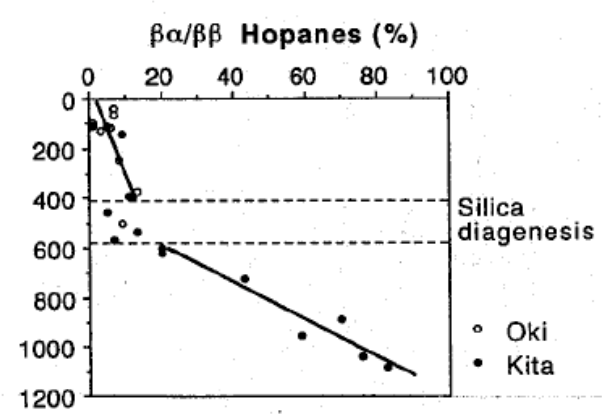

DEPTH (m)

Figure 4. Hopane parameters versus rock depth at Oki Ridge ("Oki") and Kita-Yamato Trough ("Kita"). Note the rapid increase of both parameters below the silica transition zone. 


\section{Sterane parameters}

The structural variety of sedimentary steroids provides evidence for geochemical transformations of their precursors, the eukaryotic sterols (Mackenzie et al., 1982). In the shallow sedimentary rocks from the Japan Sea, the major steranes have the $\alpha \alpha \alpha R$ configuration and extend from $\mathrm{C}_{27}$ to $\mathrm{C}_{29}$ (Figure 5). With increasing burial, the relative concentration of $\beta \alpha \alpha R$ versus $\alpha \alpha \alpha R$ steranes changes rapidly from about $25 \%$ to $40 \%$ within the silica transition zone (Figure 6). A reverse trend has been previously observed with increasing burial in Toarcian sedimentary rocks from the Paris basin (Mackenzie et al., 1980). It is therefore possible that the increase of $\beta \alpha \alpha / \alpha \alpha \alpha(\%)$ observed at the silica transition zone in Japan Sea sediments had occurred at an earlier stage of diagenesis in the Paris basin. Alternatively, the numerous mineral changes observed at the silica transition zone might have drastically modified the chemical composition of the organic matter, giving rise to a preferential formation of $\beta \alpha \alpha$-steranes. The thermodynamically more stable $\alpha \alpha \alpha$-steranes should predominate at a later stage of diagenesis. We indeed observed a decrease of $\beta \alpha \alpha / \alpha \alpha \alpha(\%)$ in the deepest sedimentary rock cored at 1082 $m$ depth (Figure 5).

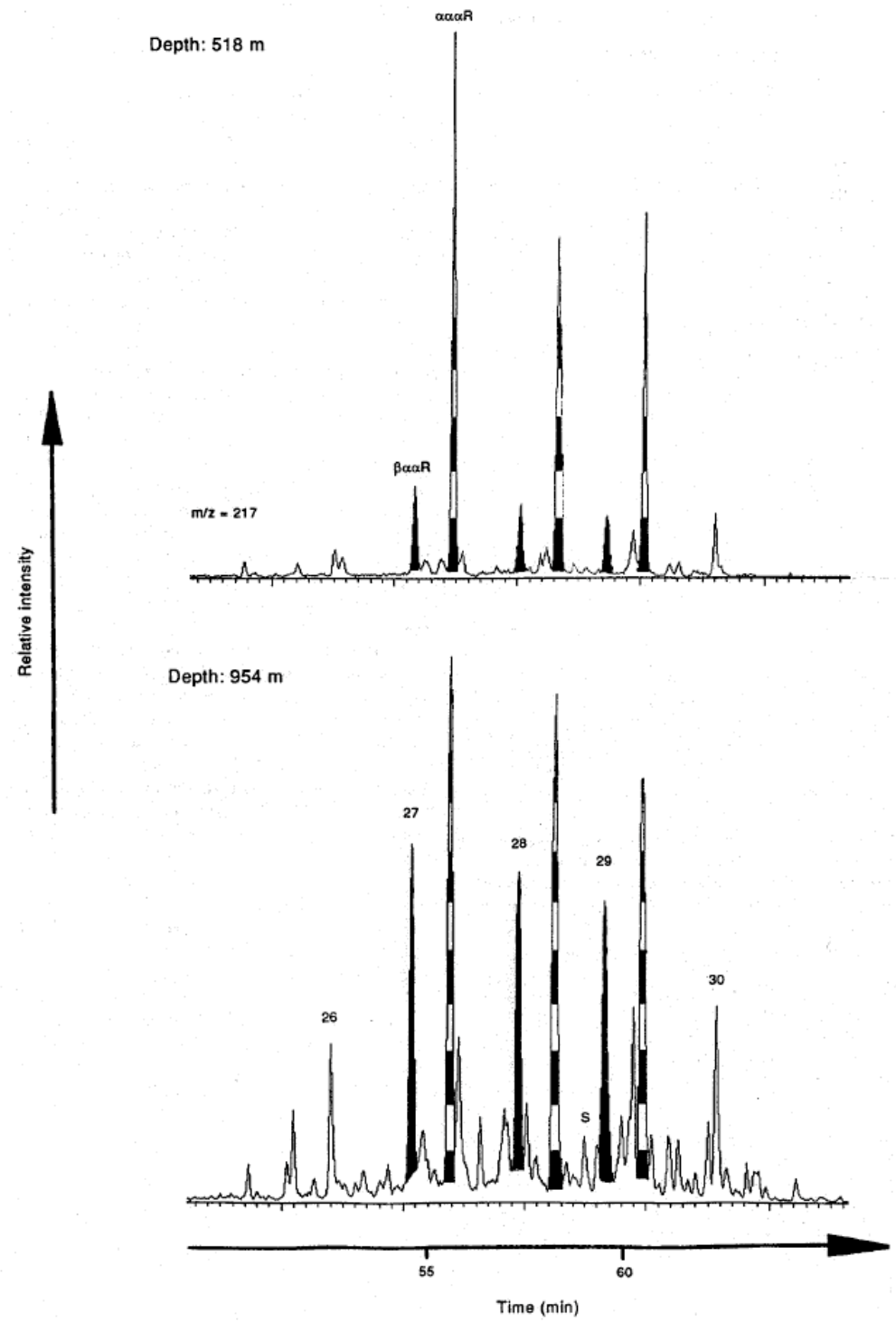

Figure 5. Reconstructed ion currents at $\mathrm{m} / \mathrm{z}=217$ showing the distributions of steranes in organic extracts of Japan Sea sedimentary rocks. Major members extend from $\mathrm{C}_{27}$ to $\mathrm{C}_{29}$ as $\alpha \alpha \alpha \mathrm{R}$ (hatched) and $\beta \alpha \alpha \mathrm{R}$ epimers (black). Note the relative increase of $\beta \alpha \alpha R$ - versus $\alpha \alpha \alpha R$ - steranes with increasing depth. Note also the low relative intensity of the $\mathrm{C}_{29} \alpha \alpha \alpha \mathrm{S}$ epimer ("S") in the sediment at $954 \mathrm{~m}$ : $\alpha \alpha \alpha \mathrm{S} \times 100 /(\alpha \alpha \alpha \mathrm{S}+$ $\alpha \alpha \alpha \mathrm{R})=13 \%$. This ratio reaches $15 \%$ in the deepest rock at $1082 \mathrm{~m}$, indicating low thermal maturity. 


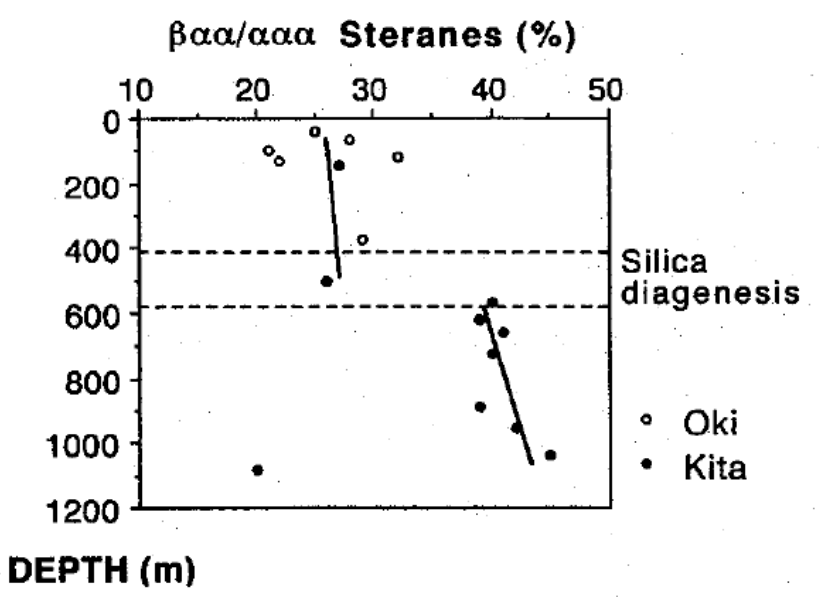

Figure 6. Sterane parameter versus depth at Oki Ridge ("Oki") and Kita-Yamato Trough ("Kita"), showing the rapid increase below the silica transition zone.

All drastic changes in chemical composition of the organic matter observed at the silica transition zone might also be explained by the contribution of different types of organic matter at the time of deposition. Such different palaeoenvironments can be evaluated by the relative amount of $\mathrm{C}_{27}-\mathrm{C}_{29}$ sterols or steranes, plotted on the triangular diagram of Huang and Meinschein (1979). Two features are obvious from examination of our sterane data in Figure 7: firstly, most of the data fall into the same area suggesting that a mixture of terrestrial and marine organic matter was initially deposited, which is in good agreement with previous petrological and Rock-Eval studies (Lichtfouse et al., 1992). Secondly, the values are not depth-related. A change in organic facies due to different initial supplies above and below the silica transition zone is therefore unlikely. Also, the various transformations of the organic matter observed in this report seem to be associated with the mineralogical changes occurring at the silica transition zone.

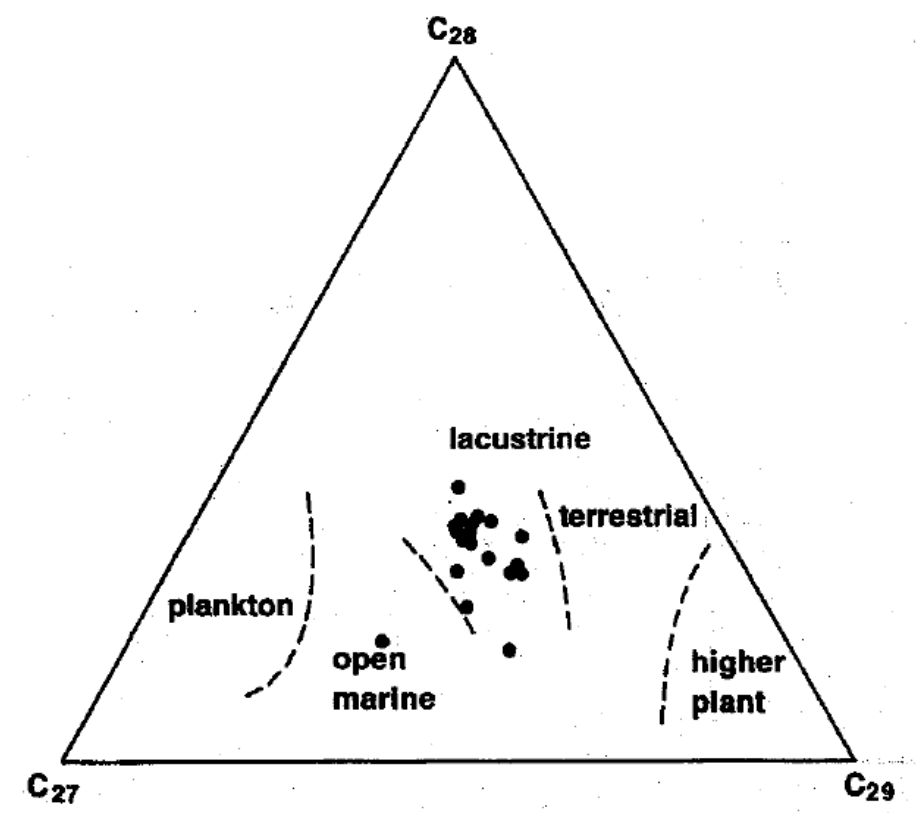

Figure 7. Huang and Meinschein diagram showing the composition of $\mathrm{C}_{27} \mathrm{C}_{28}$ and $\mathrm{C}_{29} \alpha \alpha \alpha \mathrm{R}$ steranes in Japan Sea sedimentary rocks. Those values suggest that a mixture of terrestrial and marine organic matter was initially deposited. 


\section{CONCLUSION}

Drastic increases of bitumen ratio and hopane and sterane isomerisation parameters are observed below the silica transition zone in thermally immature sedimentary rocks from the Japan Sea. Such changes suggest an acceleration of the chemical reactions in the transformation of the organic matter. This phenomenon is probably linked to the mineral and textural changes associated with the transformation of biogenic silica into authigenic silica.

\section{ACKNOWLEDGMENTS}

We are indebted to the Ocean Drilling Program for providing the core samples. We thank Drs. R. Stein, R. Seifert and W. Michaelis for helpful discussions. For technical assistance, we thank W. Laumer, A. Fischer, F. J. Keller, U. Disko and H. Willsch. Financial support by the Deutsche Forschungsgemeinschaft (grant no Ru 458/1) and the Institut National de la Recherche Agronomique is gratefully acknowledged. The quality of this manuscript has been improved by critical reviews of Drs. M. Moldowan and K. Peters.

\section{REFERENCES}

Van Dorsselaer A., Albrecht P. and Connan J. (1977a) Changes in composition of polycyclic alkanes by thermal maturation (Yallourn lignite, Australia). In Advances in Organic Geochemistry 1975 (Edited by Campos R. and Goñi J.), pp. 53-59. ENADIMSA, Madrid.

Van Dorsselaer A., Albrecht P. and Ourisson G. (1977b) Identification of novel $17 \alpha(\mathrm{H})$-hopanes in shales, coals, lignites, sediments and petroleum. Bull. Soc. Fr. Chim. 165-170.

Van Dorsselaer A., Ensminger A., Spyckerelle C., Dastillung M., Sieskind O., Arpino P., Albrecht P., Ourisson G., Brooks P. W., Gaskell S. J., Kimble B. J., Philp R. P., Maxwell J. R. and Eglinton G. (1974) Degraded and extended hopane derivatives $\left(\mathrm{C}_{27}\right.$ to $\left.\mathrm{C}_{35}\right)$ as ubiquitous geochemical markers. Tetrahedron Lett. 14, 1349-1352.

Ensminger A., Albrecht P., Ourisson G. and Tissot B. (1977) Evolution of polycyclic alkanes under the effect of burial (Early Toarcian shales, Paris basin). In Advances in Organic Geochemistry 1975 (Edited by Campos R. and Goñi J.), pp. 45-52. ENADIMSA, Madrid.

Ensminger A., Van Dorsselaer A., Spyckerelle Ch., Albrecht P. and Ourisson G. (1974) Pentacyclic triterpenes of the hopane type as ubiquitous geochemical markers : origin and significance. In Advances in Organic Geochemistry 1973 (Edited by Tissot B. and Bienner F.), pp. 245-260. Technip, Paris.

Huang W.-Y. and Meinschein W. G. (1979) Sterols as ecological indicators. Geochim. Cosmochim. Acta 43, 739-745.

Ingle J. C. Jr., Suyehiro K., von Breymann M. T. et al. (1990) Proc. ODP, Init. Repts., 128: College Station, TX (Ocean Drilling Program).

Lichtfouse E., Littke R., Disko U., Willsch H., Rullkötter J. and Stein R. (1992) Geochemistry and petrology of organic matter in Miocene to Quaternary deep sea sediments from the Japan Sea (Site 798 and 799). In Pisciotto K., Ingle J. C. Jr., von Breymann M. T., Barron J. et al., Proc. ODP, Sci. Res., 127/128, 667-675.

Mackenzie A. S., Patience R. L., Maxwell J. R., Vandenbroucke M. and Durand B. (1980) Molecular parameters of maturation in the Toarcian shales, Paris Basin, France. I. Changes in the configurations of acyclic isoprenoid alkanes, steranes and triterpanes. Geochim. Cosmochim. Acta 44, 1709-1721.

Mackenzie A. S., Brassell S. C., Eglinton G. and Maxwell J. R. (1982) Chemical fossils: the geological fate of steroids. Science 217, 491-504.

Maxwell J. R., Mackenzie A. S. and Volkman J. K. (1980) Configuration at C-24 in steranes and sterols. Nature 286, 694-697.

Moldowan J. M., Seifert W. K., Haley M. J. and Djerassi C. (1980) Proof of structure by synthesis of $5 \alpha, 14 \beta, 17 \beta(\mathrm{H})$-cholestane (20R), a major petroleum sterane. Correction with previous assignment. Geochim. Cosmochim. Acta 44, 1613.

Ourisson G., Albrecht P. and Rohmer P. (1979) The hopanoids. Paleochemistry and biochemistry of a group of natural products. Pure Appl. Chem. 51, 709-729. 
Radke M., Willsch H. and Welte D. H. (1980) Preparative hydrocarbon group type determination by automated medium pressure liquid chromatography. Anal. Chem. 52, 406-411.

Rubinstein I., Sieskind O. and Albrecht P. (1975) Rearranged sterenes in a shale : occurrence and simulated formation. J. Chem. Soc. Perkin Trans I, 1833-1836.

Seifert W. K. and Moldowan J. M. (1979) The effect of biodegradation on steranes and terpanes in crude oils. Geochim. Cosmochim. Acta 43, 111-126.

Sieskind O., Joly G. and Albrecht P. (1979) Simulation of the geochemical transformations of sterols : superacid effect of clay minerals. Geochim. Cosmochim. Acta 43, 1675-1679.

Tissot B. and Welte D. H. (1984) Petroleum Formation and Occurrence. 2nd edn. Springer, Berlin, pp. 178187.

Williams L. A., Parks G. A. and Crerar D. A. (1985) Silica diagenesis, I. Solubility controls. J. Sedim. Petrol. 55, 301-311. 